\title{
A uroguanylin-GUCY2C endocrine axis regulates feeding in mice
}

\author{
Michael A. Valentino, ${ }^{1}$ Jieru E. Lin, ${ }^{1}$ Adam E. Snook, ${ }^{1}$ Peng Li, ${ }^{1}$ Gilbert W. Kim, ${ }^{1}$ Glen Marszalowicz, ${ }^{2}$ \\ Michael S. Magee, ${ }^{1}$ Terry Hyslop, ${ }^{3}$ Stephanie Schulz, ${ }^{1}$ and Scott A. Waldman'
}

\begin{abstract}
1Department of Pharmacology and Experimental Therapeutics, Division of Clinical Pharmacology, Thomas Jefferson University, Philadelphia, Pennsylvania, USA. ${ }^{2}$ School of Biomedical Engineering, Science and Health Systems, Drexel University, Philadelphia, Pennsylvania, USA. ${ }^{3}$ Department of Pharmacology and Experimental Therapeutics, Division of Biostatistics, Thomas Jefferson University, Philadelphia, Pennsylvania, USA.
\end{abstract}

\begin{abstract}
Intestinal enteroendocrine cells are critical to central regulation of caloric consumption, since they activate hypothalamic circuits that decrease appetite and thereby restrict meal size by secreting hormones in response to nutrients in the gut. Although guanylyl cyclase and downstream cGMP are essential regulators of centrally regulated feeding behavior in invertebrates, the role of this primordial signaling mechanism in mammalian appetite regulation has eluded definition. In intestinal epithelial cells, guanylyl cyclase 2C (GUCY2C) is a transmembrane receptor that makes cGMP in response to the paracrine hormones guanylin and uroguanylin, which regulate epithelial cell dynamics along the crypt-villus axis. Here, we show that silencing of GUCY2C in mice disrupts satiation, resulting in hyperphagia and subsequent obesity and metabolic syndrome. This defined an appetite-regulating uroguanylin-GUCY2C endocrine axis, which we confirmed by showing that nutrient intake induces intestinal prouroguanylin secretion into the circulation. The prohormone signal is selectively decoded in the hypothalamus by proteolytic liberation of uroguanylin, inducing GUCY2C signaling and consequent activation of downstream anorexigenic pathways. Thus, evolutionary diversification of primitive guanylyl cyclase signaling pathways allows GUCY2C to coordinate endocrine regulation of central food acquisition pathways with paracrine control of intestinal homeostasis. Moreover, the uroguanylin-GUCY2C endocrine axis may provide a therapeutic target to control appetite, obesity, and metabolic syndrome.
\end{abstract}

\section{Introduction}

Body mass reflects central regulation of caloric consumption by enteroendocrine cells that sense nutrients in the gastrointestinal tract and secrete hormones that activate hypothalamic circuits limiting meal size (1). Although guanylyl cyclase and downstream cGMP signaling are essential regulators of feeding behavior and satiation in invertebrates $(2,3)$, the role for this primordial signaling mechanism in mammalian appetite regulation remains undefined. Guanylyl cyclase 2C (GUCY2C), principally expressed in intestinal epithelial cells (4-6), is the receptor for diarrheagenic bacterial enterotoxins (STs) (7) and the gut paracrine hormones, guanylin (8), and uroguanylin (9). This hormone-receptor system constitutes a paracrine tumor suppressing circuit whose dysregulation universally characterizes colorectal carcinogenesis $(10,11)$. Lumenal secretion of the propeptides of uroguanylin (small intestine) and guanylin (colon) stimulates intestinal GUCY2C, regulating fluid and electrolyte balance (12) and epithelial cell homeostatic programs in the gut, organizing the crypt-villus axis (13-15).

Beyond paracrine endolumenal release, these prohormones also undergo endocrine secretion by the gut into the circulation (16, 17). However, in the absence of either cognate receptors mediating extralumenal responses to these peptides $(18,19)$ or defined homeostatic mechanisms regulating their endocrine secretion from the gut (20), the precise physiological significance of the GUCY2C endocrine axis remains ambiguous. In the context of

Conflict of interest: Scott A. Waldman is the Chair of the Data Safety Monitoring Board for the C-Cure Trial sponsored by Cardio3 Biosciences and the Chair (uncompensated) of the Scientific Advisory Board to Targeted Diagnostics and Therapeutics Inc., which provided research funding that, in part, supported this work and has a license to commercialize inventions related to this work

Citation for this article: J Clin Invest. 2011;121(9):3578-3588. doi:10.1172/JCI57925 the central role of the gut-neural axis in controlling nutrient consumption and the importance of guanylyl cyclase activity in central control of invertebrate feeding, we explored the role of GUCY2C signaling in appetite regulation.

The present study reveals that eliminating GUCY2C expression in mice disrupts appetite regulation specifically by impairing satiation, producing hyperphagia associated with comorbidities, including obesity and metabolic syndrome. Corrupted satiation circuits reflect the disruption of a previously unrecognized uroguanylin-GUCY2C endocrine axis regulating appetite. Indeed, food consumption is the first physiological stimulus that induces secretion of prouroguanylin by intestinal epithelial cells into the circulation in mice and humans. This endocrine prohormone signal is selectively decoded centrally by specific proteolytic liberation of uroguanylin, but not guanylin, unexpectedly activating neuronal GUCY2C and downstream anorexigenic pathways. This study suggests that the GUCY2C-hormone axis is at the center of endocrine regulation of central appetite mechanisms and paracrine control of intestinal epithelial cell homeostasis $(14,15)$. This intersection of mechanisms regulating the acquisition of nutrients centrally and the integrity of cells mediating their processing and absorption in the gut may represent the evolutionary diversification of a more primitive guanylyl cyclase signaling pathway, regulating feeding behavior and energy homeostasis $(2,3)$. Importantly, the uroguanylin-GUCY2C endocrine axis provides what we believe to be a novel target in the emerging therapeutic armamentarium to address appetite control and the obesity pandemic (21).

\section{Results}

GUCY2C-deficient mice exhibit increased body weight, reflecting excess adiposity. Elimination of GUCY2C expression produces mice (Gucy2c/- 

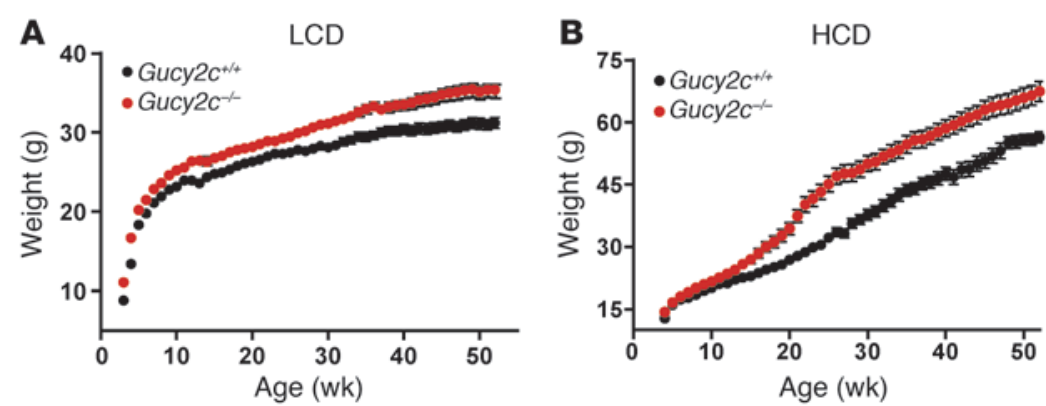

D

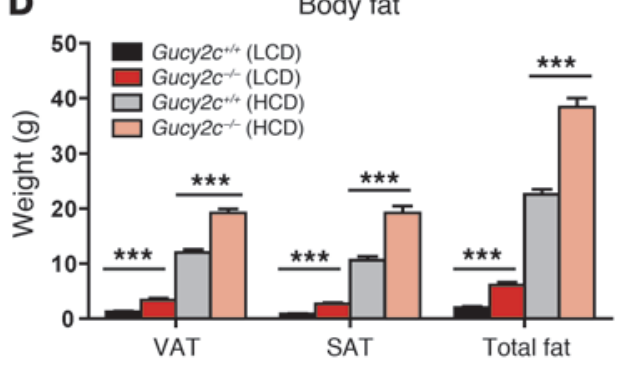

C

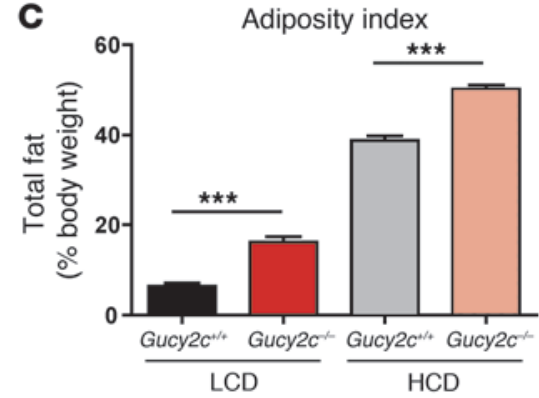

$\mathbf{E}$

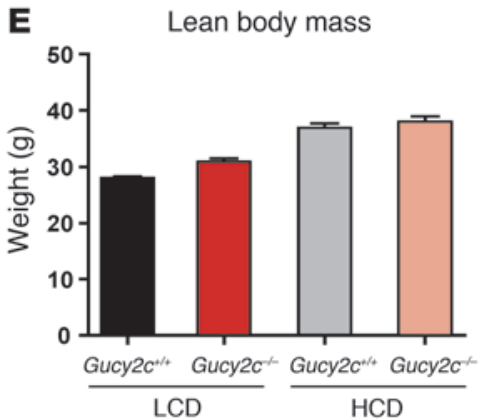

F Total body water

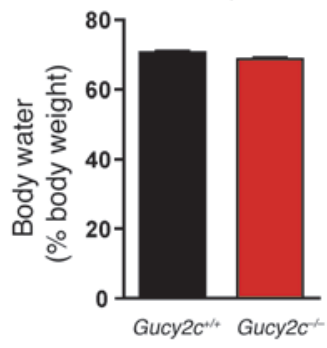

Figure 1

Gucy $2 c^{-/-}$mice exhibit increased body weight, reflecting excess adiposity. (A) Growth curves of male Gucy $2 c^{+/+}$and Gucy $2 c^{-/-}$mice raised on LCD $(n=20 ; P<0.001)$. (B) Growth curves of female Gucy2c $c^{+/+}$and Gucy2c $c^{-/}$mice raised on HCD $(n=20-40 ; P<0.01)$. (C) Adiposity index (percentage body fat) of 12-month-old mice ( $n=10-13$ per group). (D) Visceral adipose tissue (VAT), subcutaneous adipose tissue (SAT), and total adipose tissue of 12-month-old mice ( $n=10-13$ per group). (E) Quantification of lean body mass of 12-month-old mice raised on LCD or HCD $(n=10-13$ per group). (F) Total body water content of mice determined by 72 hours desiccation at $90^{\circ} \mathrm{C}(n=6)$. All data are mean \pm SEM. ${ }^{* * *} P<0.001$.

mice) resistant to induction of diarrhea by heat-stable ST (22) but susceptible to carcinogen and genetic induction of intestinal tumorigenesis $(13,14)$. Interestingly, Gucy2 $c^{-1-}$ mice raised on a standard low calorie diet (LCD) (Supplemental Table 1; supplemental material available online with this article; doi:10.1172/ JCI57925DS1) displayed accelerated growth, with $10.3 \% \pm 0.3 \%$ $(P<0.001)$ increased body mass compared with that of congenic wild-type C57BL/6 mice (Gucy2 $c^{+/+}$mice; Figure 1A). Weight differences were also produced by moderate calorie diet (MCD; Supplemental Figure 1A) or high calorie diet (HCD; Figure 1B and Supplemental Figure 1B), primarily composed of carbohydrates or fat, respectively (Supplemental Table 1). The greatest growth differential was observed in female mice raised on a HCD (23), for which Gucy2 $2 c^{-/-}$mice were $26.3 \% \pm 1.3 \%$ heavier $(P<0.01)$ than Gucy $2 c^{+/+}$mice (Figure 1B).

Excess weight in Gucy2 $2 c^{-/-}$mice was associated with greater accumulation of adipose mass and with increases in the percentage of body weight contributed by fat (adiposity index, Figure $1 \mathrm{C})$, reflecting growth in visceral and subcutaneous fat compartments (Figure 1D). In contrast, lean body mass and total body water were equivalent between genotypes (Figure 1, E and F).

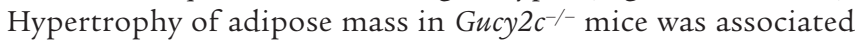
with hepatic steatosis (Figure 2, A and B) and elevated serum leptin (Figure 2C), an adipocyte-derived peptide whose circulating level reflects fat mass. Furthermore, GUCY2C deficiency amplified the metabolic syndrome associated with diet-induced obesity, including cardiac hypertrophy (Figure 2D), hyperleptinemia (Figure 2, E and F), hyperinsulinemia (Figure 2G), and impaired glycemic control (Figure 2H).
GUCY2C-deficient mice exhibit hyperphagia and diminished satiation. Gucy $2 c^{-1-}$ mice were hyperphagic, independent of sex, dietary nutrients, or dietary caloric content (Figure 3A). In that context, body masses of the genotypes were reversibly equalized by pair feeding (Figure 3B), with a direct relationship between calories consumed and weight gained (Figure 3C). Of significance, differential food consumption between genotypes was amplified by fasting, independent of dietary caloric content or nutrient composition (Figure 3D), suggesting impaired satiation. Indeed, fasted and refed Gucy $2 \mathrm{c}^{-1-}$ mice displayed deficient postprandial satiation (Figure $3 \mathrm{E}$ ), regardless of nutrients inducing the satiation response (Figure $3 \mathrm{~F}$ ).

Beyond increased calorie consumption, excess adiposity may also reflect differences in digestion, nutrient absorption, and/or energy mobilization/expenditure. In the context of the central role of dietary fat in obesity (24), lipid digestion was identical between genotypes, and triglycerides were unmeasurable (completely digested), while free fatty acid levels were comparable in stool (Figure 4A). Lipid absorption, distribution, and clearance also were equivalent with genotypes exhibiting identical serum triglyceride kinetics in the absence or presence of tyloxapol (Figure 4, B and C), which inhibits lipoprotein lipase-mediated triglyceride uptake by peripheral tissues (25). Additionally, the transcripts of rate-limiting proteins mediating lipid absorption (Fabp2), glucose absorption (Glut2, Sglt1), fatty acid and triglyceride synthesis (Fasn, Dgat1, Dgat2), and fatty acid oxidation (Acadm, $A c a d l)$ were equally expressed in intestines of the genotypes (Figure 4D). Further, energy mobilization and expenditure were equivalent, with genotypes exhibiting identical circadian activity cycles (Figure 4E) and thermoregulatory reflexes to a cold $\left(4^{\circ} \mathrm{C}\right)$ 

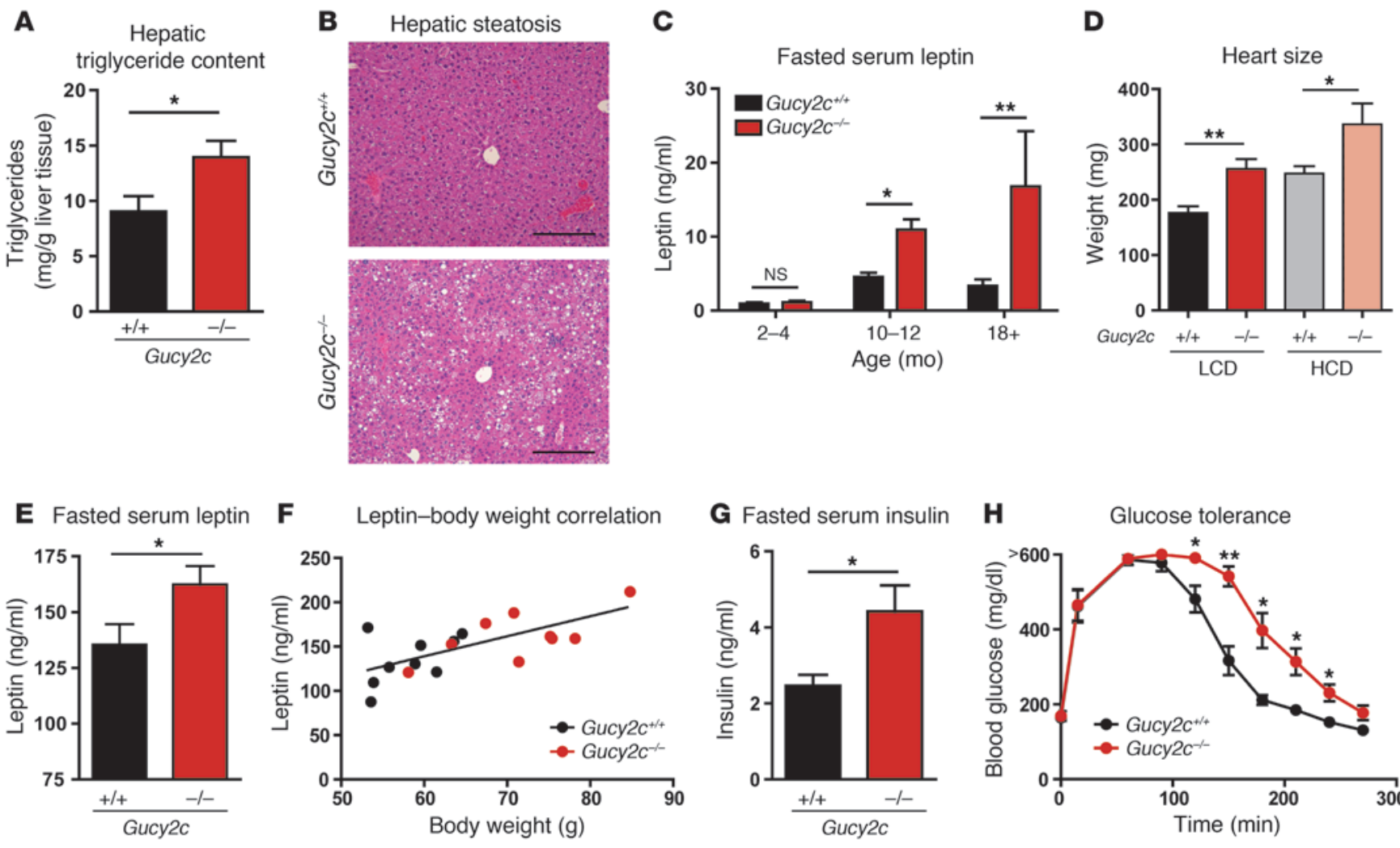

F Leptin-body weight correlation
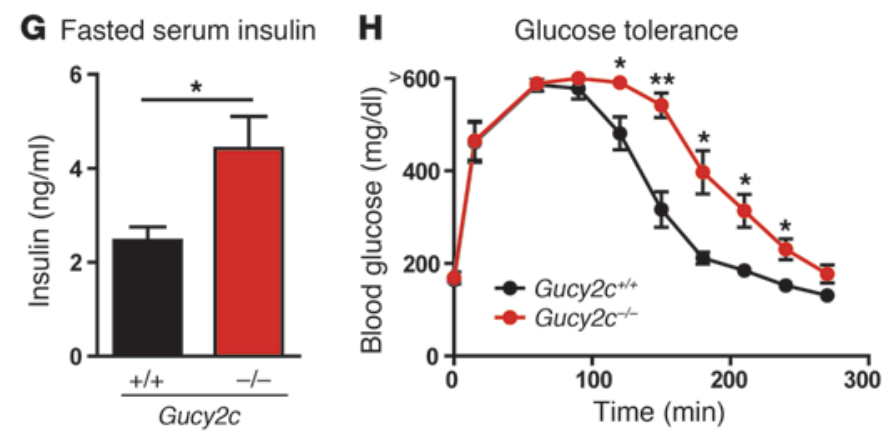

Figure 2

GUCY2C deficiency exacerbates metabolic disease. (A) Liver triglyceride content of 12-month-old mice raised on LCD $(n=19)$. (B) H\&E staining of representative left liver lobe sections of 12-month-old mice raised on LCD (scale bar: $200 \mu \mathrm{M})$. (C) Mean fasted serum leptin concentrations of mice raised on LCD ( $n=6-10$ per group). (D) Mean heart size (wet weight) of 12-month-old mice raised on LCD or HCD ( $n=10-13$ per group). (E) Mean fasted serum leptin concentrations of 12-month-old mice raised on HCD $(n=10)$. (F) Correlation of fasted serum leptin level and body weight of 12-month-old mice raised on $\operatorname{HCD}\left(r^{2}=0.47, P<0.01\right)$. The diagonal line represents a linear regression model. (G) Mean fasted serum insulin concentrations of 12-month-old mice raised on HCD $(n=10)$. $(\mathbf{H})$ Glucose tolerance test of fasted 12-month-old mice raised on HCD injected i.p. with glucose $(2.5 \mathrm{mg} / \mathrm{g})(n=6)$. All data are mean \pm SEM. NS $=P>0.05 .{ }^{*} P<0.05,{ }^{* *} P<0.01$.

environment (ref. 26 and Figure 4F). Thus, differences in these other adipogenic systems were not observed between the genotypes, establishing increased calorie consumption as the cause of the excess adiposity observed in Gucy $2 c^{-/-}$mice.

Systemic administration of GUCY2C ligands induces satiation. Eliminating GUCY2C expression did not disrupt established gut-neural axes regulating feeding, and enteroendocrine cell number (15) as well as their expression and secretion of intestinal anorexigenic peptides were equivalent in Gucy2 $\mathrm{c}^{+/+}$and $\mathrm{Gucy} 2 \mathrm{c}^{-/-}$mice (Supplemental Figure 2, A and B). Similarly, gastric emptying and gastrointestinal transit were identical between genotypes (Supplemental Figure 2C). Surprisingly, activation of intestinal GUCY2C by orally administered ST, a proteolytically resistant receptor superagonist $(27,28)$, did not alter food consumption in Gucy $2 c^{+/+}$mice (Figure $5 \mathrm{~A}$ ), eliminating a role for endolumenal GUCY2C in signaling mechanisms regulating appetite. In contrast, i.v. administration of ST induced satiation in Gucy $2 c^{+/+}$mice (Figure 5B), but not Gucy $2 c^{-/-}$mice (Figure 5C), in a dose-dependent fashion (Figure $5 \mathrm{D})$. Repeated administration of ST to mice with free access to food produced durable reductions in food consumption (Figure $5 \mathrm{E})$. Insensitivity of $\mathrm{Gucy} 2 \mathrm{c}^{-/-}$mice to the anorexigenic effects of ST was specific, as peptide YY (PYY) (Figure 5F) and cholecystokinin (CCK) (Supplemental Figure 2D) induced satiation compa- rably in both genotypes. Anorexigenic effects of systemic ST were quantitatively similar to those of PYY (Figure 5G), with a duration of action (2 hours) identical to those of glucagon-like peptide-1 (GLP-1), oxyntomodulin, and PYY (29-31).

GUCY2C expression in bypothalamus. Integration of neurohormonal signals regulating appetite occurs in the hypothalamus. Beyond intestine, Gucy2c mRNA was expressed in hypothalamus but not in extrahypothalamic brain segments or extraintestinal tissues (Figure 6A). The full-length coding sequence of Gucy2c, amplified from hypothalamic cDNA (Figure 6B), was identical to the reported sequence (NM_001127318.1; NCBI Reference Sequence). GUCY2C protein was identified in hypothalamus (Figure 6, C and D), and ST stimulated guanylyl cyclase activation and cGMP production in hypothalamic membranes (Figure $6 \mathrm{E})$. Further, central administration of ST directly into the third ventricle reduced feeding, which was quantitatively similar to the anorexigenic effect produced by exendin-4 (Figure 6F), a GLP-1 agonist that decreases feeding after i.c.v. administration (32). Gut hormones regulate appetite, in part, by modulating hypothalamic neuropeptide transcription, balancing the anorexigenic neuropeptide, proopiomelanocortin (Pomc), and the orexigenic neuropeptides, agouti-related peptide (Agrp) and neuropeptide Y (Npy) (33, 34). Hypothalamic expression of these peptides was comparable 
A
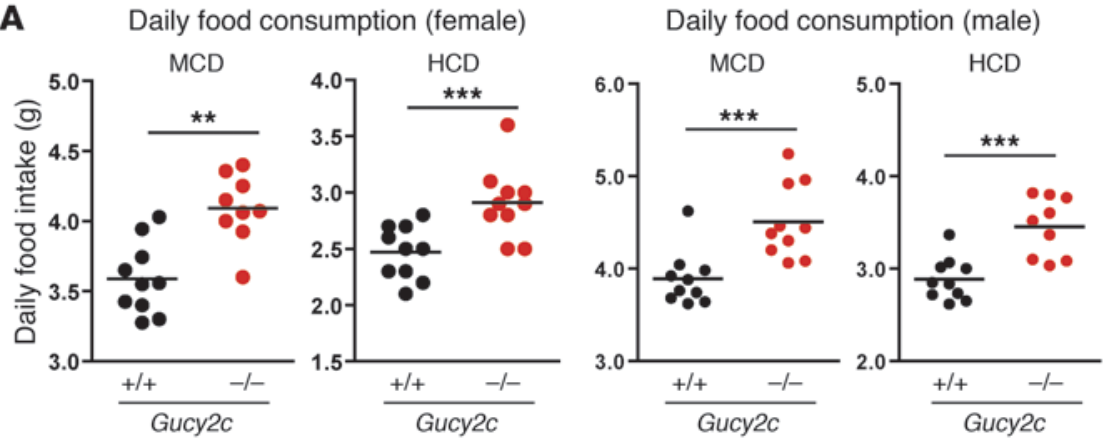

C Weight gain-hyperphagia correlation

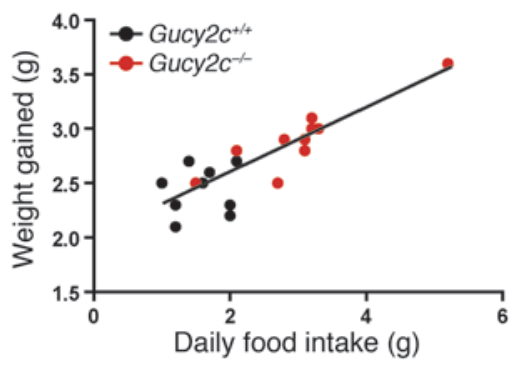

E

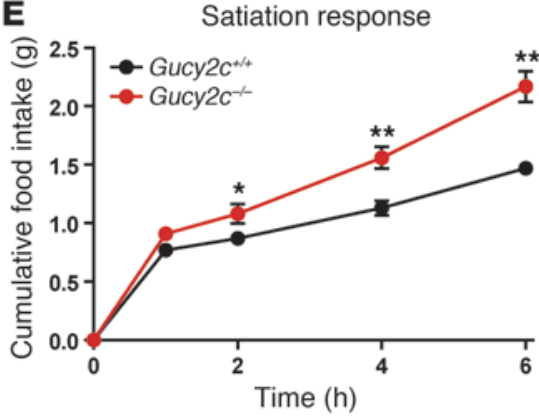

D Fasted food consumption (female)
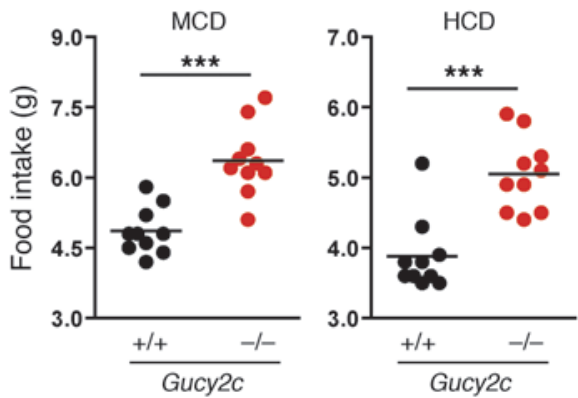

$\mathbf{F}$

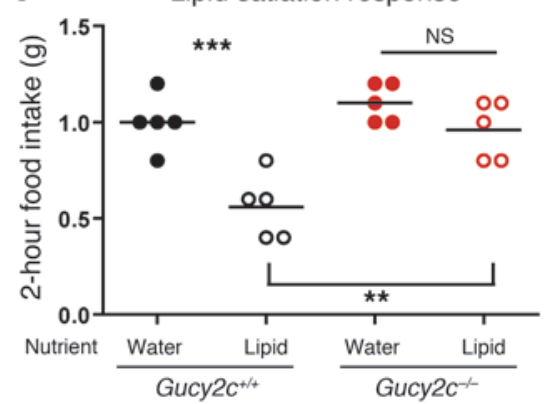

B Growth curve (pair feeding)

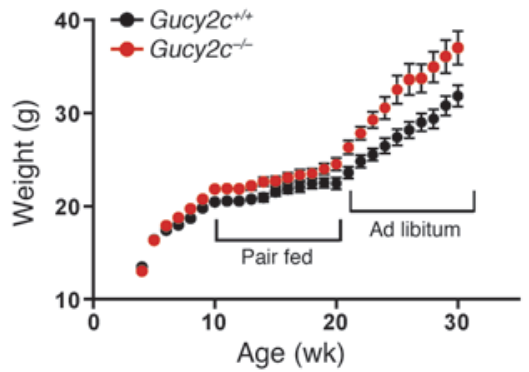

Fasted food consumption (male)
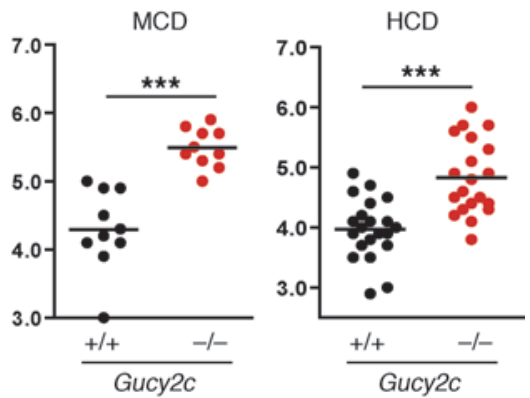

Carbohydrate satiation response

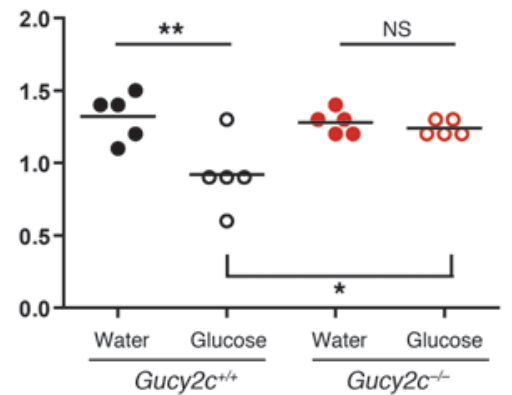

Figure 3

GUCY2C-deficient mice exhibit hyperphagia and diminished satiation. (A) Daily food consumption of 3-month-old female and male mice fed MCD or HCD. Points represent the mean of 10 daily food intake measurements ( $n=10$ per group). (B) Growth of female mice pair-fed HCD $(2.3 \mathrm{~g} / \mathrm{mouse} / \mathrm{d})(n=12)$. (C) Correlation of mean daily food intake and weight gain of 4 -month-old mice fed HCD during a 10-day period $\left(r^{2}=0.72, P<0.001\right)(n=10$ per group). The diagonal line represents a linear regression model. (D) Twenty-four-hour food intake of fasted 3- to 4-month-old female and male mice refed MCD or HCD ( $n=10-20$ per group). (E) Cumulative food intake of 3- to 4-month-old fasted mice refed HCD ( $n=10$ per group). (F) Two-hour food consumption of fasted mice gavaged with an isovolumetric bolus (300 $\mu l)$ of water, olive oil, or $35 \%$ glucose ( $n=5$ per group). All data are mean \pm SEM. Horizontal bars represent mean values. Scattergram points represent data for individual mice. ${ }^{\star} P<0.05,{ }^{* *} P<0.01,{ }^{* *} P<0.001$.

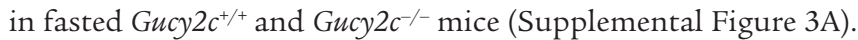
However, i.v. administration of ST selectively induced expression of Pomc mRNA without altering Npy or Agrp transcription (Figure $6 \mathrm{G}$ ), providing evidence in hypothalamus of GUCY2C activation by ST administration. Moreover, these data suggest that the anorexigenic neuropeptide, POMC, may be one downstream mediator of appetite suppression by GUCY2C.

Food stimulates intestinal prouroguanylin secretion, inducing satiation. The hypothalamus is devoid of the endogenous GUCY2C cognate ligands, Guca2a (guanylin) and Guca2b (uroguanylin) (Supplemental Figure 3B), consistent with endocrine, rather than paracrine, regulation of GUCY2C. These hormones are secreted into the circulation by the intestine as inactive propeptides $(16,17)$, which require proteolytic hydrolysis to liberate $\mathrm{C}$-terminal active peptides. Prouroguanylin, but not proguanylin, induced satiation in mice (Figure 7A), reflecting hypothalamic decoding of these endocrine signals through hormone-specific proteolytic activation (Figure 7B). Hypothalamic activation of prouroguanylin mimicked that produced by pancreas (Supplemental Figure 3C), the principle source of proteolytic liberation of uroguanylin in duodenum (35). Importantly, nutrient consumption induced endocrine secretion of prouroguanylin in mice and humans (Figure 7, C and D), with kinetics precisely corresponding to those of satiation (Figure 7C). Moreover, i.v. administration of prouroguanylin-neutral- 
A

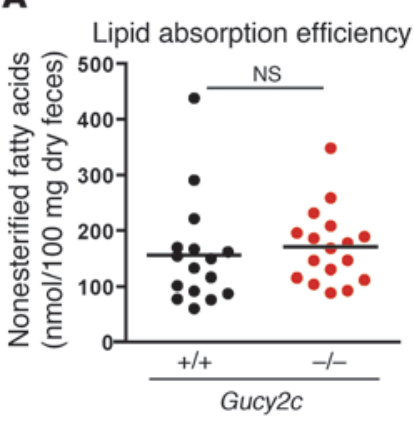

D

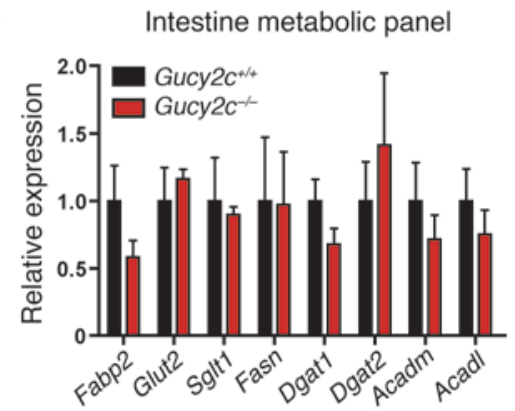

B

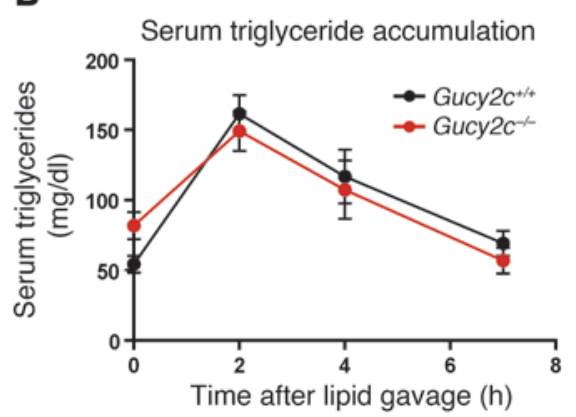

E

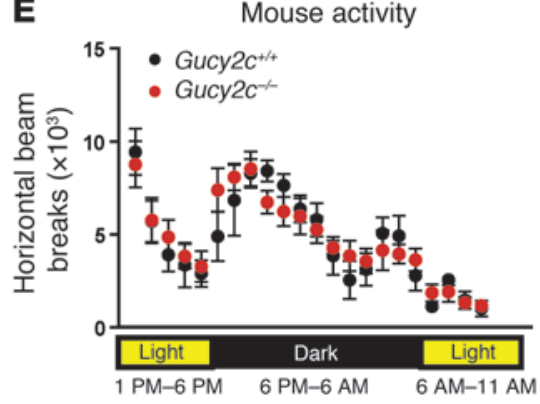

C Serum triglyceride accumulation + tyloxapol

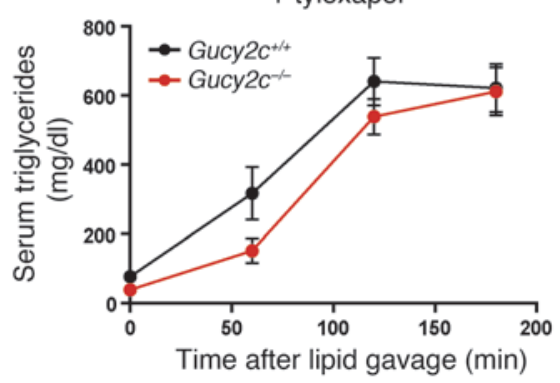

$\mathbf{F}$

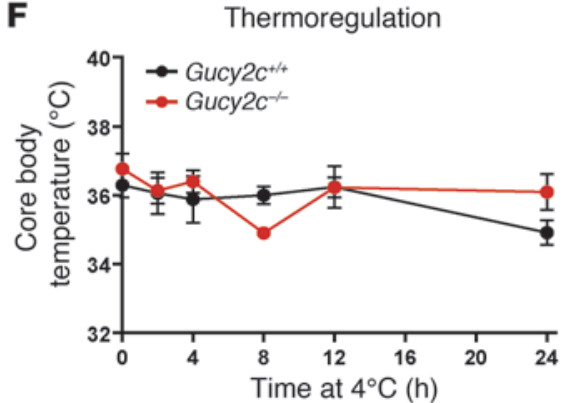

Figure 4

GUCY2C-deficient mice do not display increased lipid absorption efficiency or decreased activity/metabolic rate. (A) Free fatty acid content of feces of 3- to 4-month-old mice raised on $\operatorname{HCD}(n=16)$. Scattergram points represent data for individual mice. (B and C) Serum triglyceride concentrations of fasted mice with or without tyloxapol $(0.75 \mathrm{mg} / \mathrm{g})$ after olive oil gavage $(1.5 \mathrm{mg} / \mathrm{g})(n=5)$. (D) Levels of expression of metabolic genes in intestine, determined by qRT-PCR, normalized to Vil1 expression ( $n=4-5$ per group). (E) Daily activity patterns of Gucy2c ${ }^{+/+}$ and Gucy $2 \mathrm{c}^{-/-}$mice $(n=6)$. (F) Core body temperatures of mice exposed to a $4^{\circ} \mathrm{C}$ environment for 24 hours $(n=6)$. All data are mean \pm SEM. Horizontal bars represent mean values.

izing antibodies blocked nutrient-induced satiation (Figure 7E), confirming the role of extraintestinal endocrine GUCY2C signaling in the regulation of appetite.

\section{Discussion}

One essential element contributing to body mass homeostasis is the regulation of appetite orchestrated by endocrine cells sensing nutrient content in the gastrointestinal tract, which activate central anorexigenic circuits. In that context, nutrient-induced intestinal prouroguanylin endocrine secretion stimulating central GUCY2C, downstream anorexigenic pathways, and satiation provides unexpected insight into GUCY2C physiology. GUCY2C, a receptor principally expressed in intestinal epithelial cells (4-6), has been without a definitive role outside the gut. Further, while intestinal GUCY2C prohormones are secreted both paracrinally, regulating lumenal GUCY2C, and endocrinally, the absence of discreet stimuli inducing their secretion and defined extraintestinal receptors mediating their signaling has left the (patho)physiological significance of the GUCY2C endocrine axis ambiguous. Here, for the first time to our knowledge, the essential elements of a GUCY2C endocrine axis have been revealed: (a) a physiological stimulus (nutrient ingestion) inducing secretion of prouroguanylin into the circulation, (b) an extraintestinal GUCY2C target, and (c) a downstream consequence of endocrine hormone-receptor engagement (satiation). Moreover, signal discrimination by one receptor that binds two paracrine hormones in intestine is achieved spatially by compartmentalization, with uroguanylin and guanylin primarily expressed in small intestine and colon, respectively. In contrast, endocrine signals by these hormones are decoded for a single class of receptors outside the intestine by differential proteolytic processing of prohormones at the target organ.

For what we believe to be the first time, this GUCY2C endocrine axis mediating satiation extends evolutionarily conserved primitive cGMP-dependent circuits regulating feeding behavior across the phylogenetic continuum to mammals $(2,3)$. Signaling programs mediated by cGMP regulate food acquisition, feeding, and satiation across diverse taxa, including worms, flies, bees, and ants (3). In Drosophila, cGMP signaling inhibits nutrient consumption, particularly following brief periods of starvation, an analog of enhanced satiety (3). Similarly, in Caenorhabditis elegans cGMP is a key mediator of quiescence, the cessation of food intake that is the homolog of satiation in mammals (2). In that context, quiescence in C. elegans is specifically mediated by a membrane-bound guanylyl cyclase expressed in select neurons that control feeding (2). Moreover, elimination of cGMP signaling in C. elegans produces loss of appetite regulation and quiescence, excess consumption of nutrients, and accumulation of fat (2). This phenotype in worms precisely recapitulates excess nutrient consumption, blunting of satiation, and the resultant obesity in mice produced by eliminating GUCY2C, a membrane-bound guanylyl cyclase. Evolutionary conservation of these pathways broadly across the phylogenetic tree highlights the robust solution offered by cGMP signaling to the essential challenge of regulating nutrient acquisition in multicellular organisms (3). 

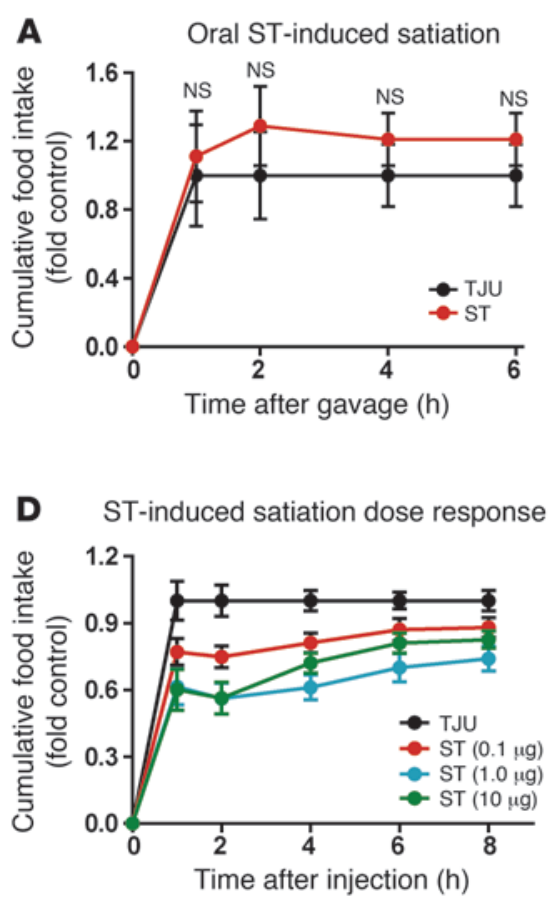
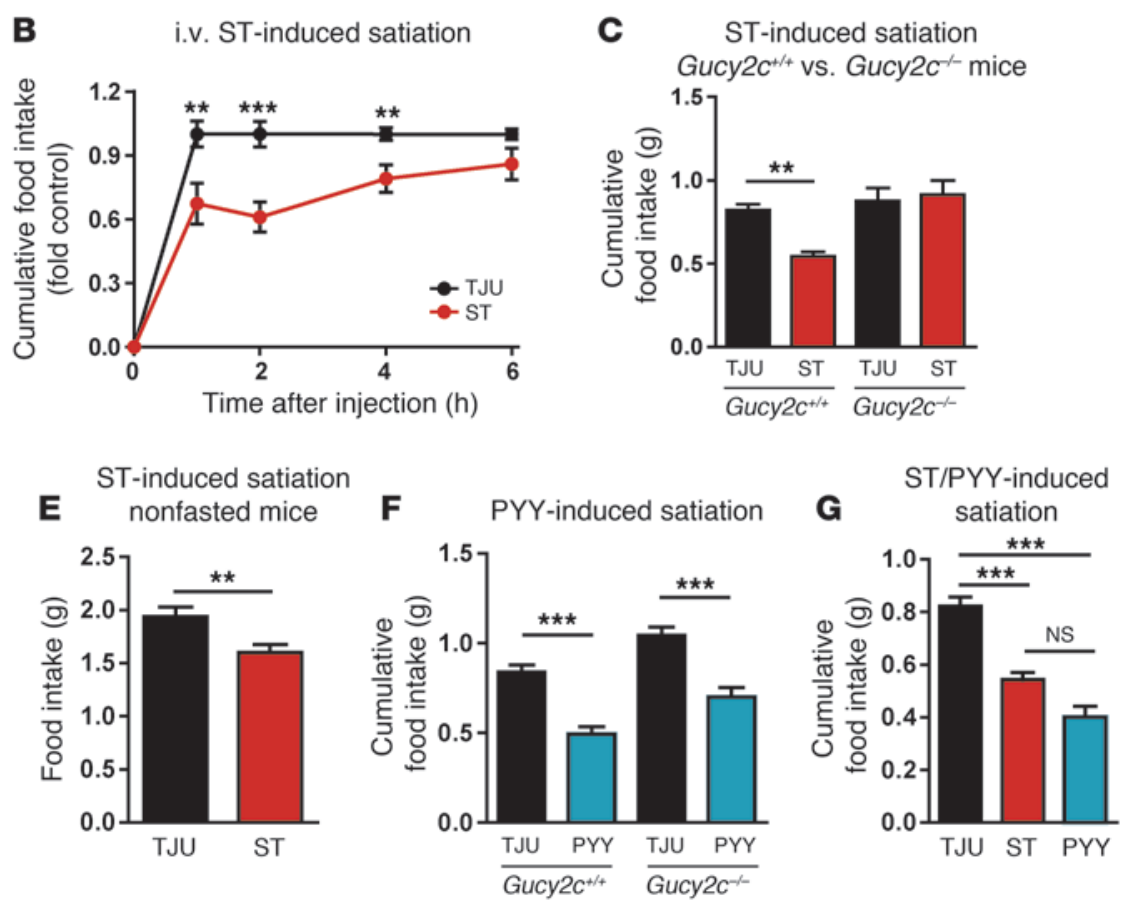

\section{Figure 5}

Systemic administration of GUCY2C ligand induces satiation. (A) Cumulative food intake of fasted Gucy2C $\mathrm{C}^{+/+}$mice orally gavaged with $1 \mu \mathrm{g}$ ST or the inactive alanine-substituted ST analogue, TJU, and refed HCD ( $n=10$ per group). (B) Cumulative food intake of fasted Gucy2 $c^{+/+}$mice

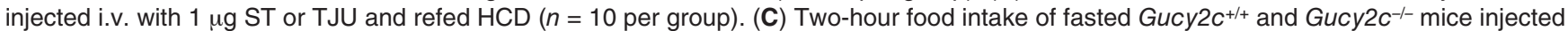
i.v. with $1 \mu \mathrm{g} \mathrm{TJU}$ or ST and refed HCD ( $n=10$ per group). (D) Cumulative food intake of fasted Gucy2c $\mathrm{C}^{+/+}$mice injected with TJU (1 $\left.\mu \mathrm{g}\right)$ or ST and refed HCD ( $n=10$ per group). (E) Twelve-hour food intake of nonfasted Gucy $2 c^{+/+}$mice fed HCD and injected with $1 \mu \mathrm{g}$ TJU or ST every 3 hours $\left(n=10\right.$ per group). (F) Two-hour food intake of fasted Gucy $2 c^{+/+}$and Gucy $2 c^{-/-}$mice injected i.v. with TJU $(1 \mu \mathrm{g})$ or PYY $(3 \mu \mathrm{g})$ and refed HCD ( $n=10$ per group). (G) Two-hour food intake of fasted Gucy $2 c^{+/+}$mice injected i.v. with TJU $(1 \mu \mathrm{g})$, ST (1 $\left.\mu \mathrm{g}\right)$, or PYY (3 $\left.\mu \mathrm{g}\right)$ and refed HCD $\left(n=10\right.$ per group). All data are mean \pm SEM. ${ }^{* \star} P<0.01,{ }^{* \star *} P<0.001$.

Satiation mediated by the GUCY2C hormone axis establishes what we believe to be the first endocrine role for this receptor in (patho)physiology. Originally isolated as a specific product of intestinal epithelial cells, GUCY2C was first identified as the receptor for bacterial heat-stable STs that induce diarrhea through cGMP-dependent regulation of fluid and electrolyte secretion (7). Identification of endogenous peptides structurally homologous to STs, including uroguanylin and guanylin in the small intestine and colon, respectively, revealed a dichotomous function for components of this system (36). These hormones are secreted lumenally in intestine in a paracrine fashion, regulating intestinal fluid and electrolyte secretion, a function homologous to STs. Moreover, GUCY2C and its paracrine hormone ligands regulate epithelial cell homeostatic processes organizing the crypt-surface axis, including the cell cycle and proliferation, metabolism, DNA damage sensing and repair, and differentiation (13-15, 37).

Beyond these established paracrine functions, guanylin and uroguanylin propeptides are secreted from intestine directly into the circulation $(36,38)$. However, the precise endocrine physiology mediated by these secreted peptides has remained incompletely defined. This uncertainty is underscored by the absence of established physiological stimuli inducing hormone secretion, receptors outside the intestine mediating downstream signaling by circulating hormones, or discreet responses produced by circulating peptides. An early hypothesis suggested that these peptides formed one link in a gut-renal endocrine axis, coordinating sys- temic fluid and electrolyte balance $(36,38)$. However, while oral and i.v. salt challenge increase local paracrine release of these peptides in gut and kidney, respectively, neither increase circulating hormone levels $(20,39)$. Also, these peptides alter renal fluid and electrolyte secretion in the absence of GUCY2C expression (18). Further, eliminating uroguanylin, but not GUCY2C, expression produces hypertension in mice (40). Moreover, while the evidence base has been ambiguous, recent studies have confirmed the absence of GUCY2C expression in kidney in placental mammals (41). Taken together, these observations demonstrate that renal effects of these peptides are mediated by paracrine signaling that is independent of GUCY2C and cGMP. By contrast, they underscore the role of GUCY2C in endocrine regulation of appetite, in which a discreet physiologic stimulus, food ingestion, induces secretion of hormone into the circulation targeting GUCY2C in hypothalamus, producing satiation.

The obesity pandemic has emerged as one of the greatest global public health threats, affecting more than 300 million adults worldwide (21). Beyond disturbances of body mass, comorbidities directly attributable to obesity, including endocrine, metabolic, and oncologic diseases, decrease patient life expectancy, with an associated economic burden exceeding $\$ 100$ billion each year in the US (42). Deconvoluting gut-brain endocrine axes regulating appetite and nutrient consumption is one principal focus for developing effective pharmacotherapies that control obesity and metabolic diseases (43). Studies here reveal a GUCY2C endocrine 
A
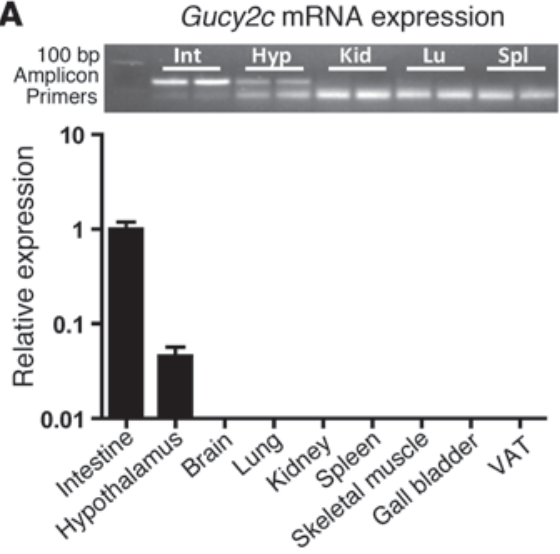

E

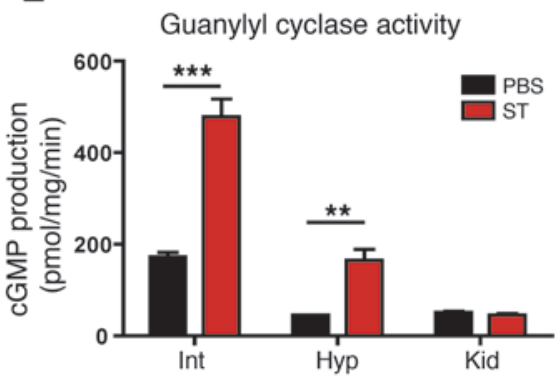

B

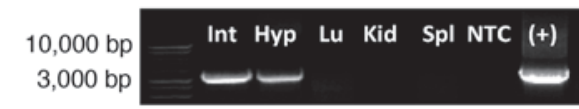

C

Gucy2c $\frac{\text { Int }}{+/+\quad-/-} \frac{\text { Hyp }}{+/+\quad-/-}$

GUCY2C

GAPDH

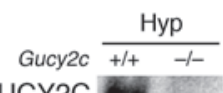

GUCY2C

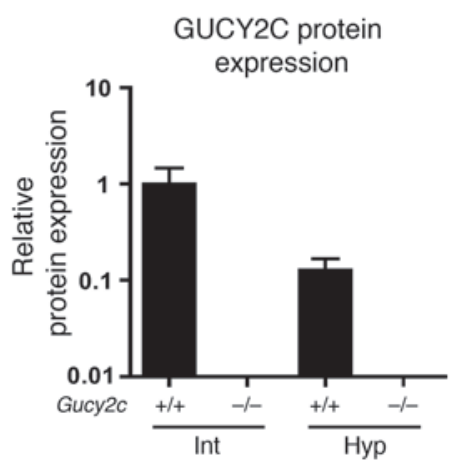

$\mathbf{F}$

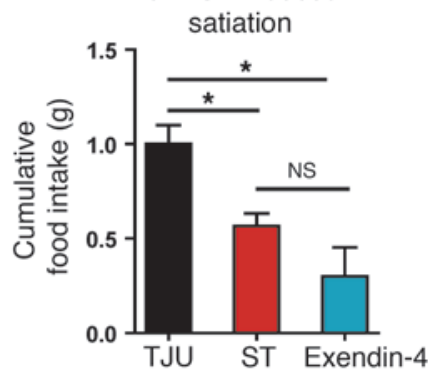

G

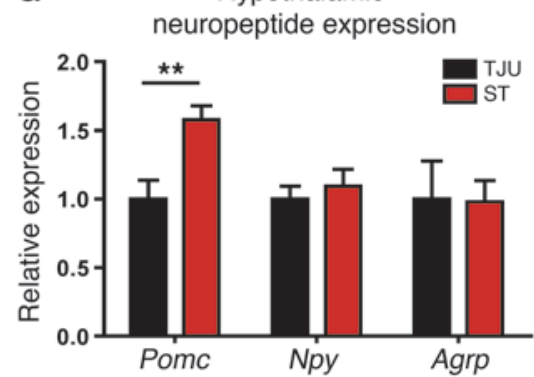

Figure 6

GUCY2C expression in hypothalamus. (A) Gucy2c expression in tissues of Gucy2c ${ }^{+/+}$mice, normalized to $\beta$-actin $($ Actb) expression $(n=4-6)$. The inset shows a representative gel image of the Gucy2c qRT-PCR products. (B) PCR products of the coding sequence of Gucy2c from cDNA prepared from Gucy $2 \mathrm{C}^{+/+}$mouse tissues. Int, intestine; Hyp, hypothalamus; Lu, lung; Kid, kidney; Spl, spleen; NTC, nontemplate control. (C) Representative immunoblot of intestine and hypothalamic GUCY2C. (D) Intestine and hypothalamic GUCY2C protein content determined by immunoblot analyses $(n=3)$. (E) Guanylyl cyclase activity of membrane preparations with or without $1 \mu$ M ST $(n=4)$. (F) Two-hour food intake of fasted Gucy $2 \mathrm{C}^{+/+}$mice after administration of TJU $(10 \mu \mathrm{g})$, ST $(10 \mu \mathrm{g})$, or exendin-4 $(1 \mu \mathrm{g})$ into the third ventricle and refed HCD $(n=3$ per group). (G) Hypothalamic expression of appetite-regulating neuropeptides, normalized to Actb expression, in fasted Gucy2c ${ }^{+/+}$mice injected i.v. with $1 \mu \mathrm{g}$ TJU or ST every 2 hours for 8 hours $(n=8)$. All data are mean \pm SEM. ${ }^{*} P<0.05,{ }^{* \star} P<0.01,{ }^{\star \star \star} P<0.001$.

circuit controlling appetite. While the impact of loss of GUCY2C signaling on body weight is smaller than that in other genetic models of obesity, such as leptin-deficient $o b / o b$ mice, this likely reflects the combined effects of this hormone on both appetite and metabolism $(44,45)$, in contrast to the uroguanylin-GUCY2C system, which appears to exclusively regulate appetite. Also, studies here do not eliminate the possibility of secondary effects of GUCY2C ligands on physiological or behavioral systems that indirectly impact appetite. Nevertheless, the present observations provide a unique opportunity to probe this pathway and its dysregulation as a possible pathophysiologic mechanism contributing to obesity and metabolic disease. Moreover, this mechanism could serve as a previously unrecognized therapeutic target for the management of weight and metabolic disease. Beyond direct GUCY2C ligand supplementation, therapeutic strategies could define mechanisms mediating intestinal release of prouroguanylin and associated oral secretagogues that elevate circulating hormone levels. Also, proteolytic pathways mediating clearance of these peptides from the circulation could be defined and inhibited to enhance effective circulating concentrations of hormone. Furthermore, unique to the uroguanylin-GUCY2C system is the proteolytic activation of the propeptide at the target site. Induction of this proteolytic sys- tem may increase the quantity of active uroguanylin at the hypothalamus and thus increase satiation. The potential for developing therapies targeted to this pathway is underscored by the recent advance of GUCY2C ligands into late-stage therapeutic trials for irritable bowel syndrome and chronic constipation (46).

Loss of GUCY2C paracrine hormone expression is a universal early event in colonic neoplasia, disrupting normal epithelial cell homeostasis, which potentiates tumorigenesis (11,37, 47-49). The present study reveals the coincidence of body mass regulation and tumor suppression by a single hormone receptor system. In that context, it is tempting to speculate that the GUCY2C hormone axis could contribute to the well-established relationship between obesity and colorectal cancer (50). In this model, a deficiency of intestinal GUCY2C hormones lies at the pathophysiologic intersection of these diseases. Thus, a deficiency in intestinal paracrine signaling contributes to tumorigenesis through corruption of epithelial homeostasis, while a deficiency in intestinal endocrine signaling promotes hyperphagia and obesity. The intriguing correlative hypothesis suggests that paracrine and endocrine supplementation of GUCY2C ligands might benefit obese patients at risk for colorectal cancer by coordinately restoring epithelial homeostasis and suppressing appetite, reversing obesity. These consider- 

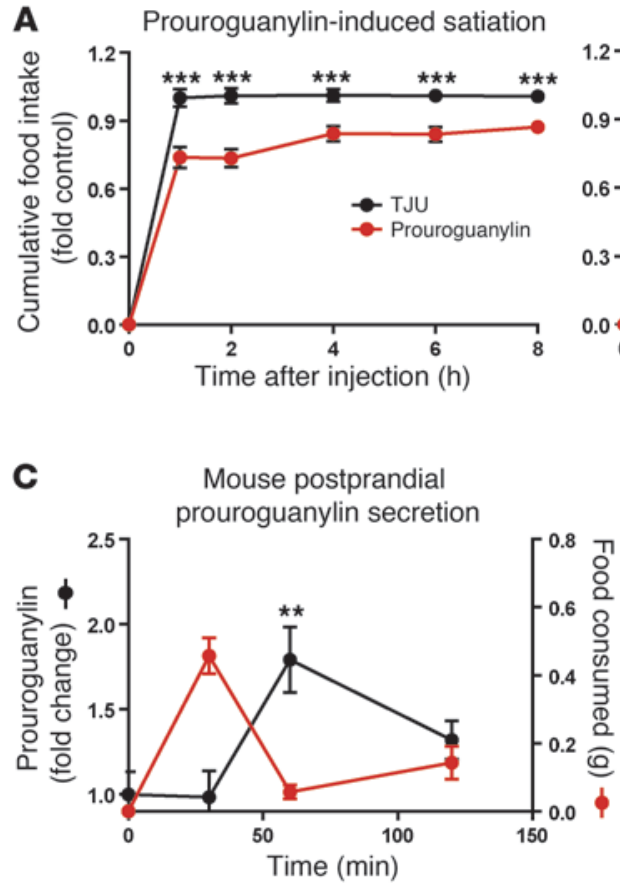

Proguanylin-induced satiation
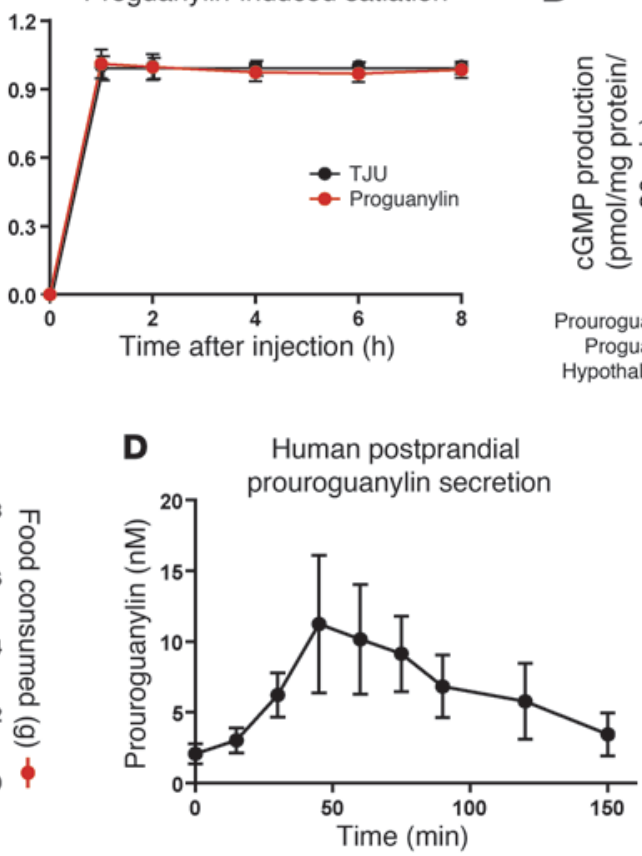

B

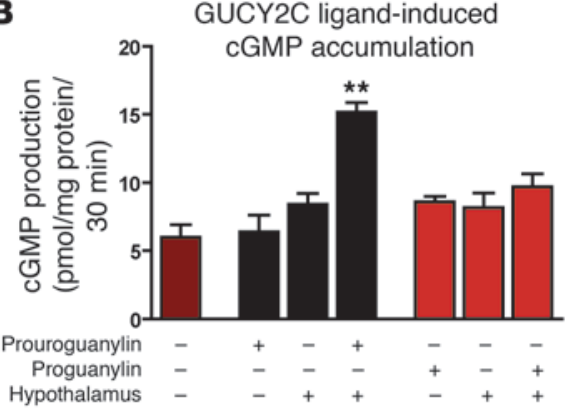

Figure 7

Food intake stimulates intestinal prouroguanylin secretion inducing central satiation. (A) Cumulative food intake of fasted Gucy2c $\mathrm{C}^{+/+}$mice injected i.v. with TJU $(10 \mu \mathrm{g})$, prouroguanylin $(10 \mu \mathrm{g})$, or proguanylin $(10 \mu \mathrm{g})$ and refed HCD $(n=10$ per group). (B) cGMP production of CT26-GUCY2C cells treated with PBS, prouroguanylin $(5 \mu \mathrm{g})$, proguanylin $(5 \mu \mathrm{g})$, hypothalamic protein $(350 \mu \mathrm{g})$, or combinations for 30 minutes (black bars, pH 5.5; red bars, $\mathrm{pH}$ 8.0; dark red bar, combined data of $\mathrm{pH}$ 5.5/8.0) ( $n=4-10$ per group). (C) Food intake and serum prouroguanylin concentrations of fasted Gucy $2 c^{+/+}$mice refed HCD $(n=7)$. (D) Serum prouroguanylin concentrations of human volunteers fasted for 12 hours and fed a standardized test meal (Supplemental Table 2) $(P<0.01$, mean postprandial [15-150 minutes] level versus fasting [0 minutes] level) $(n=9)$. (E) Food intake of fasted Gucy2C $\mathrm{C}^{+/+}$mice injected with PBS (control) or prouroguanylin antiserum (100 $\mu$ l, 1:50 dilution) during the 1- to 2-hour interval after refeeding ( $n=10$ per group). All data are mean \pm SEM. ${ }^{\star} P<0.05,{ }^{* \star} P<0.01,{ }^{\star \star \star} P<0.001$.

ations underscore the significance of further exploring the pathophysiological role of the GUCY2C hormone axes in mechanisms underlying colorectal cancer and obesity.

Beyond regulating fluid and electrolyte balance and epithelial dynamics in intestine, GUCY2C mediates an extraintestinal endocrine axis controlling satiation. This role for GUCY2C signaling in modulating appetite provides a previously missing evolutionary link between primordial and mammalian signaling programs regulating feeding behavior. In the context of the expanding global obesity pandemic and the associated paucity of effective management options, the GUCY2C endocrine axis offers what we believe to be a novel therapeutic opportunity to regulate appetite, restrict nutrient consumption, and defend against obesity.

\section{Methods}

Mice. Gucy2c-/- mice were generated by the insertion of a neomycin cassette into exon 1 and subsequent homologous recombination with embryonic stem cells (22). Gucy2 $c^{-1-}$ mice were backcrossed with C57BL/6 mice for more than 10 generations to produce Gucy2 $2 c^{-/-}$congenic C57BL/6 mice and wild-type $\left(\mathrm{Gucy} 2 \mathrm{c}^{+/+}\right)$littermates. Colony-bred Gucy2 $2 c^{+/+}$mice were used

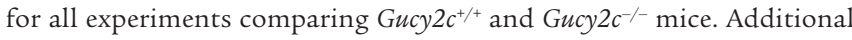
8- to 10-week-old C57BL/6 mice were purchased from the National Cancer Institute Animal Production Program. C57BL/6 (8- to 10-week-old) mice, which were surgically implanted with i.c.v. cannulas into the third ventricle, were obtained from The Jackson Laboratory. Animals were maintained in a pathogen-free, temperature-controlled $\left(20^{\circ} \mathrm{C}\right)$, and 12 -hour-light/dark cycle environment, with free access to food and water. All mouse studies were conducted under approved protocols and in agreement with the animal ethical guidelines of the Thomas Jefferson University Institutional Animal Care and Use Committee.

Reagents. Reagents used included native ST and the inactive analog $\mathrm{ST}(5-17) \mathrm{Ala},{ }^{9,17} \mathrm{Cys}(\mathrm{Acm}),{ }^{5,10}$ 6-14 disulfide (herein referred to as TJU; Bachem). CCK and PYY were obtained from Phoenix Pharmaceuticals Inc. Prouroguanylin and proguanylin were obtained from BioVendor R\&D. Exendin-4 was obtained from California Peptide Research Inc. The prouroguanylin antiserum (antibody 6910) was provided by Michael Goy (University of North Carolina, Chapel Hill, North Carolina, USA) (51).

Cell lines. BALB/c-derived CT26 colorectal cancer cells were obtained from ATCC. This cell line lacks endogenous GUCY2C, established by radiolabeled ligand binding and quantitative RT-PCR (qRT-PCR) analyses (52). For the generation of the stable CT26 cell line expressing GUCY2C, RNA was purified from mucosal scrapings of the jejunum of a 3-month-old C57BL/ 6 mouse. RT-PCR was performed using Ex-Taq (Takara) to amplify cDNA, which was cloned into pENTR/D-TOPO (Invitrogen) and subcloned into pMSCV2.2-Puro to generate Gucy2c-pMSCV2.2-Puro. CT26 cells were transduced with retrovirus produced from $293 \mathrm{~T}$ cells that were transiently transfected with pCL-Ampho (Imgenex) and Gucy2c-pMSCV2.2-Puro, followed by selection with $50 \mu \mathrm{g} / \mathrm{ml}$ puromycin (EMD Chemicals) (52).

Growth curves. For generation of the growth curves, mice were placed on low calorie Lab Diet Rodent Diet 5010 (Purina Mills), moderate calorie TestDiet Rodent Diet 58 Y2 (Purina Mills), or high calorie TestDiet Rodent Diet 58Y1 (Purina Mills) (Supplemental Table 1) at weaning (3 weeks old), and weights 
were measured weekly. Visceral adipose tissue, subcutaneous adipose tissue, and heart weights were measured by gross dissection and weighing.

Metabolic studies. For studies using blood, mice were anesthetized by isoflurane, and blood was collected into EDTA-coated tubes by poking the vascular bundle within the submandibular area with a sterile animal lancet (Braintree Scientific). Serum leptin and insulin levels of mice fasted overnight (16 hours) were quantified by ELISA (Crystal Chem). For glucose tolerance tests, mice were fasted overnight (16 hours) and injected (i.p.) with glucose $(2.5 \mathrm{mg} / \mathrm{g})$. An approximately $1-\mathrm{mm}$ segment was amputated from the tail, and approximately $5 \mu$ l of blood was placed on a glucose test strip and quantified using an Accu-Chek Aviva meter system.

Hepatic triglyceride measurements. Lipids were extracted from the liver using the Folch method $(53,54)$. Briefly, a section of the left liver lobe of each mouse was weighed and placed in $3 \mathrm{ml}$ of chloroform/methanol (2:1), homogenized, and agitated in an orbital shaker at room temperature. Homogenates were centrifuged at $425 \mathrm{~g}$, and supernatants recovered and washed with 0.2 volumes of $0.9 \% \mathrm{NaCl}$ solution. After mixing, supernatants were centrifuged at $425 \mathrm{~g}$, and the upper aqueous phase was aspirated. The lower organic phase containing lipids was dried by vacuum centrifugation, pellets were resuspended in isopropanol/triton X (9:1), and triglycerides were quantified with a colorimetric Triglyceride Determination Kit (Sigma-Aldrich).

Fecal fat measurements. Fecal pellets of 3- to 4-month-old mice raised on $\mathrm{HCD}$ were dried by vacuum centrifugation and weighed, and lipids were extracted. Nonesterified free fatty acids were quantified using the colorimetric HR Series NEFA-HR(2) Kit (Wako Diagnostics).

Serum triglyceride measurements. Mice were fasted overnight (16 hours) and anesthetized with isoflurane, and blood was collected for fasting measurements. Mice were then gavaged with olive oil (mixture of oleic acid, linoleic acid, and linolenic acid; $1.5 \mathrm{mg} / \mathrm{g}$; Fluka) and replaced in their cages without food, blood was collected at subsequent time points, and serum triglycerides were quantified using a colorimetric Triglyceride Determination Kit (Sigma-Aldrich). For experiments measuring serum triglyceride accumulation in the absence of peripheral triglyceride uptake, mice were injected with tyloxapol $(0.75 \mathrm{mg} / \mathrm{g}$; Sigma-Aldrich), and $30 \mathrm{~min}$ utes later fasting blood was collected. Mice were then gavaged with olive oil $(1.5 \mathrm{mg} / \mathrm{g})$, blood was collected at subsequent time points, and serum triglycerides were quantified.

Activity measurements. Individual mice were placed in a Versamax Animal Activity Monitor daily at 13:00 hours, with free access to food and water, and activity was monitored until 11:00 hours the following day. Activity measurements were conducted within the animal facility in the controlled environment described above.

Thermoregulation. Mice were placed at $4{ }^{\circ} \mathrm{C}$, and core body temperature was recorded using a Physitemp RET- 3 mouse rectal probe connected to a Physitemp BAT-12 microprobe electronic thermometer.

Food intake studies. Mice were acclimated to individual wire-mesh cages for 1 week or more. Daily food consumption for each mouse was measured at the same time daily for 10 days and averaged. In fasted food intake studies, mice were fasted for 16 hours before evaluation.

Pair feeding. Gucy $2 c^{+/+}$and Gucy2c $c^{-/-}$mice (10-week-old females) raised on HCDs were separated into individual cages and fed $2.3 \mathrm{~g} / \mathrm{mouse} / \mathrm{d}$ of $\mathrm{HCD}$, the greatest amount ensuring equivalent food intake. Food was replaced daily, and body weights were measured weekly. After 10 weeks of restricted diet, mice were given ad libitum access to the diet, and body weights were measured weekly.

Satiation responses. Mice (3 months old) raised on HCD were acclimated for 1 week in wire-mesh cages, fasted overnight, and provided preweighed amounts of HCD, and food consumption was measured after refeeding. For nutrient-induced satiation (55), 3-month-old mice were gavaged with
$300 \mu \mathrm{l}$ of $\mathrm{dH}_{2} \mathrm{O}, 35 \%$ glucose, or olive oil and provided preweighed amounts of $\mathrm{HCD}$ (high fat) $\left(\mathrm{dH}_{2} \mathrm{O}\right.$ vs. lipid) or MCD (high carbohydrate) $\left(\mathrm{dH}_{2} \mathrm{O}\right.$ vs. glucose), and consumption was measured for 2 hours after refeeding.

Gut transit time. Gut transit time was quantified (56) in fasted mice by administering FITC-labeled dextran (70,000 MW; Sigma-Aldrich) by gavage (100 $\mu \mathrm{l}$ of a $5-\mathrm{mg} / \mathrm{ml}$ solution prepared in PBS combined with $100 \mu$ l olive oil) and 10 minutes later harvesting the entire gastrointestinal tract, from stomach to rectum. Small intestine was subdivided into 9 equal sections, and colon was subdivided into 2 equal sections. The stomach, small intestinal sections, and colon sections were placed in separate tubes containing $1 \mathrm{ml}$ PBS ( $5 \mathrm{ml}$ for stomach), segments were opened, and lumenal contents were suspended by vortexing. Fluorescence was quantified in a POLARStar Optima multiwell fluorescence plate reader (excitation at $485 \mathrm{~nm}$; emission at $530 \mathrm{~nm})$ (BMG Labtech).

Intestinal and circulating satiety hormone measurements. Epithelia from jejunum and ileum were collected, and protein was extracted in M-PER reagent (Pierce). Jejunum samples were assayed for CCK, and ileum samples were assayed for GLP-1 and PYY by ELISA (Phoenix Pharmaceuticals), and results were normalized to total protein. Blood also was collected, and circulating CCK and GLP-1 were quantified by ELISA.

Oral and i.v. peptide-induced satiation. For oral ligand-induced satiation, acclimated and fasted mice were gavaged with TJU (control peptide) or ST $(1 \mu \mathrm{g}$ in $100 \mu \mathrm{l}$ PBS $)$ and subsequently provided a HCD, and consumption was quantified after refeeding. For i.v. ligand-induced satiation, acclimated and fasted mice received i.v. (100 $\mu \mathrm{l}) \mathrm{TJU}(1-10 \mu \mathrm{g})$, ST (1 $\mu \mathrm{g})$, PYY (3 $\mu \mathrm{g})$, CCK $(1 \mu \mathrm{g})$, prouroguanylin $(10 \mu \mathrm{g})$, proguanylin $(10 \mu \mathrm{g})$, or prouroguanylin antiserum (1:50 in PBS). Mice were then provided a HCD, and consumption was quantified after refeeding.

Quantitative real-time PCR. To quantify Gucy2c, satiety hormone receptor (Leprb, Cckar, Glp1r, Npy2r), and hypothalamic neuropeptide (Pomc, Npy, Agrp) expression, RNA was extracted using the RNeasy Lipid Tissue Mini Kit (Qiagen) and subjected to one-step RT-PCR using TaqMan EZ RT-PCR Core Reagents and specific primer/probes from TaqMan Gene Expression Assays (Applied Biosystems). RT-PCR was conducted using an ABI Prism 7000 Sequence Detection System (Applied Biosystems). Relative expression was calculated with the $2^{-\Delta \Delta C T}$ method, using $\beta$-actin $(A c t b)$ as a reference. To quantify expression of intestinal metabolic proteins, extracted RNA was converted to cDNA using AMV reverse transcriptase (Roche) and $\mathrm{p}(\mathrm{dt})_{15}$. The cDNA was subjected to RT-PCR using the SYBR Green PCR Master Mix (Applied Biosystems) and specific primer sets (Supplemental Table 3). RT-PCR was conducted as above, and relative expression was calculated using villin (Vil1) as a reference.

Mouse GUCY2C monoclonal antibody generation. The monoclonal antibody (MS20) recognizing mouse GUCY2C was generated by priming Gucy2c-1mice with $1 \times 10^{8}$ IFU GUCY2 $\mathrm{C}_{\mathrm{ECD}}-\mathrm{AV}$ by i.m. injection. The truncated GUCY2 $\mathrm{C}_{1-430}$-expressing adenovirus (GUCY2 $\mathrm{C}_{\mathrm{ECD}}-\mathrm{AV}$ ) was generated as described previously (52). Three weeks later, mice were boosted i.p. with $2.5 \times 10^{7}$ CT26-GUCY2 $\mathrm{C}_{\mathrm{TM}}$ cells in an incomplete Freund's adjuvant. Mice were injected with $25 \mu \mathrm{g}$ purified GUCY2 $\mathrm{C}_{\mathrm{ECD}}$ i.v. in PBS 3 days before spleen collection. $\mathrm{GUCY} 2 \mathrm{C}_{\mathrm{ECD}}$ protein was purified as described previously (52). Spleens were collected 26 days after initial priming and fused with the mouse myeloma cell line Sp2/0-Ag14 (ATCC) to create hybridomas using the ClonaCell-HY Hybridoma Cloning Kit (Stemcell Technologies). Positive clones were screened by detection of purified $\mathrm{GUCY} 2 \mathrm{C}_{\mathrm{ECD}}$ in ELISA (52). After 3 rounds of limiting dilution to ensure stability and clonality, the MS20 hybridoma was grown in the BD CELLine Disposable Bioreactor (BD Biosciences), and antibody was purified from supernatants using a protein $\mathrm{G}$ column.

Immunoblot analyses. Membrane proteins were extracted from tissues using MEM-PER reagent (Pierce) supplemented with protease inhibitors 
(Roche). GUCY2C protein expression was quantified by immunoblot anal-

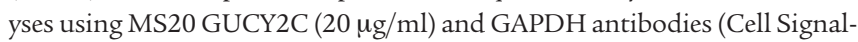
ing Technology). Staining intensity of specific GUCY2C bands, quantified by densitometry, was normalized to the staining intensity of GAPDH.

Guanylyl cyclase activity. Intestinal mucosal scrapings, hypothalami, and kidneys of Gucy $2 \mathrm{c}^{+/+}$mice were homogenized in ice-cold TEED buffer (50 mM Tris-HCl, 1 mM EDTA, 1 mM EGTA, 1 mM DTT, 0.1 mM PMSF, $\mathrm{pH}$ 7.5) containing protease and phosphatase inhibitors (Roche). Homogenates were centrifuged at $425 \mathrm{~g}$ for 10 minutes at $4^{\circ} \mathrm{C}$, and supernatants were centrifuged at $100,000 \mathrm{~g}$ for 60 minutes at $4^{\circ} \mathrm{C}$. Pellets were resuspended in TEED buffer, and protein concentration was quantified (BCA protein assay; Pierce). Guanylyl cyclase activity was quantified by ligand-induced cGMP production (57), and cGMP was measured by radioimmunoassay.

GUCY2C ligand-induced cGMP accumulation. Hypothalamus and pancreas homogenates were prepared in DMEM $(200 \mu \mathrm{l})$ and centrifuged at $250 \mathrm{~g}$ for 5 minutes at $4{ }^{\circ} \mathrm{C}$, supernatants were collected, and protein concentrations were quantified (BCA protein assay; Pierce). Prouroguanylin $(5 \mu \mathrm{g})$ or proguanylin $(5 \mu \mathrm{g})$ were incubated with tissue extracts $(3.5 \mathrm{mg}$ protein $/ \mathrm{ml})$ or DMEM for 1 hour at $37^{\circ} \mathrm{C}$ (final volume $=100 \mu \mathrm{l}$ ). Digests were then brought to a final volume of $220 \mu \mathrm{l}$ with DMEM plus IBMX (1 mM). Prouroguanylin digests were adjusted to a $\mathrm{pH}$ of 5.5 and proguanylin digests were adjusted to a $\mathrm{pH}$ of 8.0, the optima for uroguanylin and guanylin binding and activation of GUCY2C, respectively (35). CT26-GUCY2C cells, pretreated with IBMX $(1 \mathrm{mM})$, were incubated for 30 minutes with $100 \mu \mathrm{l}$ of each digest. These cells also were treated with DMEM plus IBMX (1 mM) ( $\mathrm{pH} 5.5$ or 8.0 ) to quantify basal cGMP production. cGMP production was quantified by radioimmunoassay (15).

i.c.v. peptide-induced satiation. Mice, which had a cannula surgically implanted into the third ventricle, were purchased and acclimated for 3 weeks to individual cages with wire-mesh floors and HCD. Mice were fasted overnight and then lightly anesthetized with isoflurane for insertion of injector cannulae into guide cannulae. TJU $(10 \mu \mathrm{g}), \mathrm{ST}(10 \mu \mathrm{g})$, and exendin-4 $(1 \mu \mathrm{g})$, each diluted to a final volume of $5 \mu \mathrm{l}$ with sterile PBS, were injected at a rate of $1 \mu \mathrm{l} / \mathrm{min}$ for 5 minutes using an Ultra Microsyringe Pump and a Micro4 Controller (World Precision Instruments Inc.). After peptide administration, mice were placed into individual cages and provided preweighed amounts of HCD, and consumption was quantified after refeeding.

Serum prouroguanylin ELISA. Immunosorbent plates (Nunc) were coated with prouroguanylin antiserum $(1: 1,000)$. The immunogenic prouroguanylin peptide (PALPLDLQPVCASQE) was diluted in SuperBlock T20 PBS Blocking Buffer (Pierce) to generate a standard curve (range, $1 \mu \mathrm{g} / \mathrm{ml}-10$ $\mathrm{pg} / \mathrm{ml} ; 630 \mathrm{nM}-0.01 \mathrm{nM}$ ). Serum samples were diluted in blocking buffer (1:10), and standard solutions and samples were added to the plate. Biotinylated immunogenic peptide was diluted to a final concentration of $1 \mathrm{ng} / \mathrm{ml}$ in blocking buffer and added to the plate. Plates were incubated for 30 minutes at $37^{\circ} \mathrm{C}$ and washed, and signals were visualized with streptavidin-HRP (BD Biosciences).

Human prouroguanylin measurements. Human prouroguanylin was measured in healthy male volunteers (age, $31.7 \pm 10.5$ years; BMI, $23.0 \pm 2.3$ $\mathrm{kg} / \mathrm{m}^{2}$ ) fasted for 12 hours prior to arrival at the investigation center. A cannula was inserted into an anticubital vein, and blood was drawn prior to receiving the test meal (Supplemental Table 2; 0 minutes) and at time points postprandially. All subjects gave written informed consent for the study, and approval was obtained from the Thomas Jefferson University institutional review board (control no. 10D-154).

Statistics. Lipid- and carbohydrate-induced satiation and GUCY2C ligand-induced cGMP accumulation were analyzed by 1-way ANOVA with Tukey's multiple comparisons test. Correlations of leptin-body weight and weight gain-food consumption were analyzed by Pearson correlation. Animal weight growth curves were analyzed by fitting Weibull models to each sex, genotype, and diet combination, using $\mathrm{k}=2,000$ nonparametric bootstrap confidence intervals for inference, to account for the varying number of animals available over time in the growth experiments. Food intake after prouroguanylin antiserum treatment was analyzed using a linear-mixed model of the natural logarithm of food intake, with effects for treatment, time, and treatment $\times$ time completed. A linear contrast for the a priori hypothesis was generated, providing the least-squares mean estimate and $P$ value. Mouse and human prouroguanylin secretion was analyzed using mixed-effect linear regression with fixed effects for time and a random intercept term to account for correlation among repeated measurements from the same subject, with censoring for values below the limit of quantification. The mean prouroguanylin level at each postprandial time was compared with the mean fasting level. $P$ values were adjusted using Hochberg's method to account for multiple comparisons. Student's $t$ test or Welch's $t$ test (for tests with unequal intergroup variances) were used for all other analyses. All statistical tests were 2 sided, and $P$ values of less than 0.05 were considered statistically significant. Statistical analyses were completed in SAS v9.2 and GraphPad Prism software.

\section{Acknowledgments}

These studies were supported by grants from NIH (CA75123, CA95026, CA146033) and Targeted Diagnostics and Therapeutics. M.A. Valentino is the recipient of a predoctoral award from the Pharmaceutical Research and Manufactures of America Foundation. P. Li was enrolled in the NIH-supported institutional K30 Training Program In Human Investigation (K30 HL004522) and was supported by NIH institutional award T32 GM08562 for Postdoctoral Training in Clinical Pharmacology. S.A. Waldman is the Samuel M.V. Hamilton Endowed Professor. We thank L. Bennett, D. Merry, S. Croker, B. Leiby, J. Haaf, C. Bonaccorso, A. Bombonati, L. Eisenman, J. Farber, M. Oshinsky, and M. Cooper for their contributions to this research. The prouroguanylin antibody was a gift from M. Goy (University of North Carolina).

Received for publication March 8, 2011, and accepted in revised form June 29, 2011.

Address correspondence to: Scott Waldman, 132 South 10th Street, 1170 Main, Philadelphia, Pennsylvania 19107, USA. Phone: 215. 955.6086, Fax: 215.955.7006, E-mail: Scott.Waldman@jefferson.edu.
1. Badman MK, Flier JS. The gut and energy balance: visceral allies in the obesity wars. Science. 2005; 307(5717):1909-1914.

2. You Yj, Kim J, Raizen DM, Avery L. Insulin, cGMP, and TGF- $\beta$ signals regulate food intake and quiescence in C. elegans: A model for satiety. Cell Metabolism. 2008;7(3):249-257.

3. Kaun KR, et al. Natural variation in food acquisition mediated via a Drosophila cGMP-dependent protein kinase. J Exp Biol. 2007;210(pt 20):3547-3558.

4. Carrithers SL, et al. Guanylyl cyclase $C$ is a selective marker for metastatic colorectal tumors in human extraintestinal tissues. Proc Natl Acad Sci U S A. 1996;93(25):14827-14832.

5. Carrithers SL, Parkinson SJ, Goldstein S, Park P, Robertson DC, Waldman SA. Escherichia coli heatstable toxin receptors in human colonic tumors. Gastroenterology. 1994;107(6):1653-1661.

6. Swenson ES, Mann EA, Jump ML, Witte DP, Giannella RA. The guanylin/STa receptor is expressed in crypts and apical epithelium throughout the mouse intestine. Biochem Biophys Res Commun. 1996;225(3):1009-1014.

7. Schulz S, Green CK, Yuen PS, Garbers DL. Guany- lyl cyclase is a heat-stable enterotoxin receptor. Cell. 1990;63(5):941-948.

8. Currie MG, et al. Guanylin: An endogenous activator of intestinal guanylate cyclase. Proc Natl Acad Sci US A. 1992;89(3):947-951.

9. Hamra FK, et al. Uroguanylin: Structure and activity of a second endogenous peptide that stimulates intestinal guanylate cyclase. Proc Natl Acad Sci US A. 1993;90(22):10464-10468.

10. Zhang L, et al. Gene expression profiles in normal and cancer cells. Science. 1997;276(5316):1268-1272. 11. Steinbrecher KA, et al. Expression of guanylin is down- 
regulated in mouse and human intestinal adenomas. Biochem Biophys Res Commun. 2000;273(1):225-230.

12. Vaandrager AB, Bot AG, De Jonge HR. Guanosine $3^{\prime}, 5^{\prime}$-cyclic monophosphate-dependent protein kinase II mediates heat-stable enterotoxin-provoked chloride secretion in rat intestine. Gastroenterology. 1997;112(2):437-443.

13. Lin JE, et al. The hormone receptor GUCY2C suppresses intestinal tumor formation by inhibiting AKT signaling. Gastroenterology. 2010;138(1):241-254.

14. Li P, et al. Guanylyl cyclase C suppresses intestinal tumorigenesis by restricting proliferation and maintaining genomic integrity. Gastroenterology. 2007;133(2):599-607.

15. Li P, Lin JE, Chervoneva I, Schulz S, Waldman SA, Pitari GM. Homeostatic control of the crypt-villus axis by the bacterial enterotoxin receptor guanylyl cyclase $\mathrm{C}$ restricts the proliferating compartment in intestine. Am J Pathol. 2007;171(6):1847-1858.

16. Nakazato $M$, et al. Identification of $10-\mathrm{kDa}$ proguanylin as a major guanylin molecule in human intestine and plasma and its increase in renal insufficiency. Biochem Biophys Res Commun. 1994; 205(3):1966-1975

17. Moss NG, et al. Uroguanylin, an intestinal natriuretic peptide, is delivered to the kidney as an unprocessed propeptide. Endocrinology. 2008;149(9):4486-4498.

18. Carrithers SL, et al. Guanylin and uroguanylin induce natriuresis in mice lacking guanylyl cyclaseC receptor. Kidney Int. 2004;65(1):40-53.

19. Sindic A, et al. Uroguanylin and guanylin regulate transport of mouse cortical collecting duct independent of guanylate cyclase C. Kidney Int. 2005; 68(3):1008-1017.

20. Fukae H, Kinoshita H, Fujimoto S, Kita T, Nakazato M, Eto T. Changes in urinary levels and renal expression of uroguanylin on low or high salt diets in rats. Nephron. 2002;92(2):373-378.

21. WHO. The World Health Report 2002. Reducing risks, promoting healthy life. Geneva, Switzerland: WHO; 2002

22. Schulz S, Lopez MJ, Kuhn M, Garbers DL. Disruption of the guanylyl cyclase-C gene leads to a paradoxical phenotype of viable but heat-stable enterotoxinresistant mice. J Clin Invest. 1997;100(6):1590-1595.

23. Hong J, Stubbins R, Smith R, Harvey A, Nunez N. Differential susceptibility to obesity between male, female and ovariectomized female mice. NutrJ. 2009;8:11.

24. Anzai K, Fukagawa K, Iwakiri R, Fujimoto K, Akashi $\mathrm{K}$, Tso P. Increased lipid abssorption and transport in the small intestine of zucker obese rats. J Clin Biochem Nutr. 2009;45(1):82-85.

25. Goudriaan JR, et al. Intestinal lipid absorption is not affected in CD36 deficient mice. Mol Cell Bio chem. 2002;239(1-2):199-202.

26. Trayhurn P, Fuller L. The development of obesity in genetically diabetic-obese $(\mathrm{db} / \mathrm{db})$ mice pair-fed with lean siblings. The importance of thermoregulatory thermogenesis. Diabetologia. 1980;19(2):148-153.

27. Greenberg RN, et al. Comparison of effects of uroguanylin, guanylin, and Escherichia coli heat-stable enterotoxin STa in mouse intestine and kidney: evidence that uroguanylin is an intestinal natriuretic hormone. J Investig Med. 1997;45(5):276-283.

28. Hamra FK, Eber SL, Chin DT, Currie MG, Forte LR. Regulation of intestinal uroguanylin/guanylin receptor-mediated responses by mucosal acidity. Proc Natl Acad Sci US A. 1997;94(6):2705-2710.

29. Turton MD, et al. A role for glucagon-like peptide-1 in the central regulation of feeding. Nature. 1996; 379(6560):69-72

30. Dakin CL, et al. Peripheral oxyntomodulin reduces food intake and body weight gain in rats. Endocrinology. 2004;145(6):2687-2695.

31. Batterham RL, et al. Critical role for peptide YY in protein-mediated satiation and body-weight regulation. Cell Metab. 2006;4(3):223-233.

32. Baggio LL, Huang Q, Brown TJ, Drucker DJ. Oxyntomodulin and glucagon-like peptide- 1 differentially regulate murine food intake and energy expenditure. Gastroenterology. 2004;127(2):546-558.

33. Challis BG, Pinnock SB, Coll AP, Carter RN, Dickson SL, O'Rahilly S. Acute effects of PYY3-36 on food intake and hypothalamic neuropeptide expression in the mouse. Biochem Biophys Res Commun. 2003;311(4):915-919.

34. Morris DL, Rui L. Recent advances in understanding leptin signaling and leptin resistance. Am J Physiol Endocrinol Metab. 2009;297(6):E1247-E1259.

35. Hamra F, et al. Prouroguanylin and proguanylin: purification from colon, structure, and modulation of bioactivity by proteases. Endocrinology. 1996;137(1):257-265.

36. Forte LR Jr. Uroguanylin and guanylin peptides: pharmacology and experimental therapeutics. Pharmacol Ther. 2004;104(2):137-162.

37. Pitari GM, et al. The paracrine hormone hypothesis of colorectal cancer. Clin Pharmacol Ther. 2007; 82(4):441-447.

38. Sindic A, Schlatter E. Cellular effects of guanylin and uroguanylin. J Am Soc Nephrol. 2006;17(3):607-616.

39. Elitsur $\mathrm{N}$, et al. The proximal convoluted tubule is a target for the uroguanylin-regulated natriuretic response. J Pediatr Gastroenterol Nutr. 2006; 43(suppl 1):S74-S81.

40. Lorenz JN, Nieman M, Sabo J. Urouganylin knockout mice have increased blood pressure and impared natriuretic response to enteral $\mathrm{NaCl}$ load. J Clin Invest. 2003;112(8):1244-1254.

41. Qian X, Moss NG, Fellner RC, Taylor-Blake B, Goy MF. The rat kidney contains high levels of prouroguanylin (the uroguanylin precursor) but does not express GC-C (the enteric uroguanylin receptor). Am J Physiol Renal Physiol. 2011;300(2):F561-F573.

42. Wyatt SB, Winters KP, Dubbert PM. Overweight and obesity: prevalence, consequences, and causes of a growing public health problem. Am J Med Sci. 2006;331(4):166-174

43. Valentino MA, Lin JE, Waldman SA. Central and peripheral molecular targets for antiobesity pharmacotherapy. Clin Pharmacol Ther. 2010;87(6):652-662.

44. Breslow MJ, Min-Lee K, Brown DR, Chacko VP, Palmer D, Berkowitz DE. Effect of leptin deficiency on metabolic rate in ob/ob mice. Am J Physiol. 1999; 276(3 pt 1):E443-E449.

45. Halaas JL, et al. Weight-reducing effects of the plasma protein encoded by the obese gene. Science. 1995;269(5223):543-546.

46. Andresen V, et al. Effect of 5 days linaclotide on transit and bowel function in females with constipation-predominant irritable bowel syndrome. Gastroenterology. 2007;133(3):761-768.

47. Birkenkamp-Demtroder K, et al. Gene expression in colorectal cancer. Cancer Research. 2002; 62(15):4352-4363.

48. Cohen MB, Hawkins JA, Witte DP. Guanylin mRNA expression in human intestine and colorectal adenocarcinoma. Lab Invest. 1998;78(1):101-108.

49. Notterman DA, Alon U, Sierk AJ, Levine AJ. Transcriptional gene expression profiles of colorectal adenoma, adenocarcinoma, and normal tissue examined by oligonucleotide arrays. Cancer Res. 2001; 61(7):3124-3130.

50. Renehan AG, Tyson M, Egger M, Heller RF, Zwahlen $M$. Body-mass index and incidence of cancer: a systematic review and meta-analysis of prospective observational studies. Lancet. 2008;371(9612):569-578.

51. Qian X, Moss NG, Fellner RC, Goy MF. Circulating prouroguanylin is processed to its active natriuretic form exclusively within the renal tubules. Endocrinology. 2008;149(9):4499-4509.

52. Snook AE, et al. Guanylyl cyclase C-induced immunotherapeutic responses opposing tumor metastases without autoimmunity. J Natl Cancer Inst. 2008; 100(13):950-61

53. Folch J, Lees M, Sloane Stanley GH. A simple method for the isolation and purification of total lipides from animal tissues. J Biol Chem. 1957;226(1):497-509.

54. Mok KK, Sun HH, Se YC. Effect of herbal extract mixtures on serum and liver lipid metabolism in chronic ethanol - Administered rats. J Health Sci. 2006;52(4):344-351.

55. Bellissimo N, Anderson GH. Cholecystokinin-A receptors are involved in food intake suppression in rats after intake of all fats and carbohydrates tested. J Nutr. 2003;133(7):2319-2325.

56. Samuel BS, et al. Effects of the gut microbiota on host adiposity are modulated by the short-chain fatty-acid binding $\mathrm{G}$ protein-coupled receptor, Gpr41. Proc Natl Acad Sci U S A. 2008;105(43):16767-16772.

57. Parkinson SJ, Jovanovic A, Jovanovic S, Wagner F, Terzic A, Waldman SA. Regulation of nitric oxideresponsive recombinant soluble guanylyl cyclase by calcium. Biochemistry. 1999;38(20):6441-6448. 